\title{
Of Cyclones and Bovines: Living in the Torrid Zone
}

\author{
Susan Hawthorne \\ James Cook University, Townsville
}

\section{Anthem to the green tree frog Litoria infrafrenata}

Your croak wakes me from deathlike sleep just as the seasons pause to reincarnate. 3 am and the world hinge is swinging: opening closing, the live and the dead are parting.

You wake the dead croaking through the layers of evolution from your spot next to the screendoor. The Mandukya is in my ears, the brahmins and the frogs chanting their circular breathing.

Daily I wonder at the painted glee of your colour, green so green it would make the Irish envious-I find you sitting in camouflage on the edge of a leaf or, as tonight, belly-flat

against the glass door waiting for insectsI've found you visible as daylight, as still as the soughing night air atop the iron railings. You play tricks on tourists hiding inside the flange

of the toilet bowl so forever after they'll see those tiny flat-ended hands graspingit's humour and the joy of colour-and of course the transforming midnight croak. (Hawthorne 2009: 9)

$\mathrm{I}$ grew up on a farm on the Western Slopes of New South Wales where in a good year the annual rainfall was 18 inches $(450 \mathrm{~mm})$. That amount of rain can fall in a matter of days in Far North Queensland and the frogs are of a size and colour that was unimaginable to me who had handled only the tiny frogs of the drylands. To top it off, in the last five years I have endured two Category-5 cyclones, Larry and Yasi both of which hit us at Mission Beach where I spend my summers and as much of the year as I can. And then I went to India, South India where the monsoons fill the streets with water.

\section{Cyclones and cassowaries}

The tropical world is one in which excess is the norm. An excess of rain; an excess of no rain. The rhinoceros beetle a creature baroque in its excess of size and badly 
designed landing plans. The curlew with its ghostly call like a keening wind or the python lying in digestive torpor with its wallaby belly. The Hercules moth as big as a bat or the giant butterflies that wing in on a depression. The frigate birds, sea eagles and the cassowary or their smaller cousins, the drongo, bee-eater and thrill-seeking sunbirds. Beneath the surface, there's the cow-faced dugong, leatherback turtles and a host of sea creatures.

The plant world is just as voracious. Trees become like forests in just a few years; vines stretch their tendrils around trunks and taps and verandah posts. Mangos drop on the road and are so numerous no one stops to gather them up. The cassowary follow the fruiting plants: the lilly pilly, the white apple, the Davidson plum and all the mangos hanging from the tree.

I wrote the following poem as a celebration of the cycles of growth one sees on a single walk up Bicton Hill.

\section{Bicton Hill}

Consider the geometry of the spiral

Fibonacci Pythagoras Archimedes

a nautilus shell a sunflower

the curl of a cyclone

walk the spiral path

to the top of Bicton Hill-

walk recursively

in parallel

the sea eagle rises hillside

through the thermals

its way faster and smoother-

the walking path is open

and shaded, rough and flat

white cockatoos screech their

flight over the tree tops

a flight of squawked delight

small seed pods, bright

coloured leaves-red

yellow, green-dot the way

step around the mound

left by the cassowary, the red

fruits of palms digested

this forest has survived more

cyclones than any human

will endure, its tall trees 


\author{
grounded by vines and \\ keeled buttressed roots \\ so many lives at each storey- \\ canopy, trunk, root-the earth \\ beside it hosting those ancient \\ cycad palms grown tall with time \\ circle the hill looking \\ out over tropical beaches \\ island resorts, farms and forests \\ the finger of the Clump \\ points seaward, lies low \\ on the sea, shelters the curl \\ of Boat Bay where dugong \\ graze and developers dredge \\ plans for a pointless marina \\ this hill with its layers of life \\ -fruit, flowers, insects, birds- \\ will go on being what it is \\ buzzing life inside its own zone \\ the hill a cone of activity \\ a monument of solidity (Hawthorne 2009: 5-6)
}

Then come the cyclones. After Cyclone Larry I was obsessed with trying to capture that experience: the build up, the waiting, the sense of amazement that wind could blow so hard. And afterwards, the silence, the skeleton trees, the leaf-pasted walls, the sadness and the nightmares. This became my book, Earth's Breath which takes its title from a quote from the Rig-Veda: Where was earth's breath, blood and soul?

\title{
Earth's breath
}

Breath is an origin story before breath is non-existence winds ride the edge of the storm cloud messengers galloping loud orchestral kettle drums beat.

Summer has been long its breath has spanned millennia and now comes the rain the storm, the raging rotten breath of cyclonic winds.

Myths are made of such noise 
the rampages of Heracles

have filled our childhood ears

the violence of men and gods

he sneezes and we all fall down.

Who will be Delilah, brave enough

to calm Samson with a pair of

scissors, his long hair fallen

trampled like old vines that

strangle the biggest trees?

We arenot so lucky with

Larrikin Larry, no shears large

enough to make his pate shine

as we watch, the ground turns bald

with his blunders through the undergrowth.

A shredder over his shoulder, Larry

larks about turning bark and leaves

to confetti and in his next breath

plays graffiti artist, pasting every

wall door and window.

But even wind needs to draw breath

a moment's stillness, earth's smoko-

then we hear the trampling across the roof

the flue knocked off, the guttering

torn ripped and discarded

as Larry changes direction, running rings

widdershins, bellowing earth's grief

no longer at play, this brat is serious

his blood has curdled, our souls are rattled

ears drumming against bawling Larry. (Hawthorne 2009: 22-23)

\section{Bovines and Monsoons}

Just after the publication of Earth's Breath I went to India on an Asialink Literature Residency. My plan was to write a collection of poems called Cow. At the time I was immersing myself in Sanskrit and Tamil poetry. The Sanskrit text I was reading via a class at La Trobe University was the Harivamsa where you get lines like the following: "16. The sun seemed to be sinking into the belly of the new clouds where the deep waters hang, gushing and bellowing." (Translation: Susan Hawthorne) ${ }^{1}$

1 The Harivamsa is an ancient Indian text related to the Mahäbhārata that dates to around the second century BCE. 
In the Sangam tradition of Tamil language there are poems like that by Cittalai Cattanar $^{2}$ a work from the sixth century entitled Akananuru 134.

Rains in season,

forests grow beautiful.

Black pregnant clouds

bring the monsoon, and stay.

Between flower and blue-gem

flower on the bilberry tree

the red-backed moths multiply

and fallen jasmines

cover the ground. (Ramanujan 2008: 76)

After a visit to the gardens that make up the Theosophical Society which contains some unimaginable huge banyan trees, I found myself writing this poem: what she says about nomadic life.

\section{what she says about nomadic life}

there are two ways of walking in the world

you can walk along a path in which your

colourful garments are a rainbow

or you can walk with your limbs

strung with ropes and string so you

resemble the downward pointing roots

of banyan trees in motion an ocean

of sound such as arises when a great herd

of cattle sways along a dusty road (Hawthorne 2011a: 120)

In translating Sanskrit poetry also, these experiences of tropical excess spill over into the text. I have written a free form translation of Kalidasa's poem Meghadüta (Cloud Messenger) which contains these lines:

as the wind drives you slowly slowly

the cātaka bird sings sweetly sweetly

skeins of cranes are in flight

cloud seeded they fly in formation

like a garland aloft pleasing to

the sky-turned eye (Hawthorne 2012)

As I wrote this, I could see the frigate birds and the pelicans who flew over in the silence after Cyclone Larry.

In India even the cows are bigger than anywhere else. There is an ancient species, the gaur who can sometimes be seen in the National Parks, where one day I got a glimpse of a herd on the hillside.

2 This name is sometimes spelt Seethalai Saathanar. 


\section{what she says about gaur}

immoveable

ancient as diamonds

old as song

gaur are statues against green

mountains

ridge their backs

verbs crest the ends

of sentences

heads

a saddle between

where water gathers in the wet

the female line

zigzags

the sloped hillside

the dual feminine

Matagavam

mother of the gaur

stands like a giant fortress

at the base

inverting the mountain

top

early risers

greet the day

moaning low

at night

a multitude

of sickle moons

graze

long-sighted eyes

horns almost a circle

pale summer grass

coloured

rufous coats shining

beneath a harvest moon

Matagavām: Sanskrit: cow mother. (Hawthorne 2011: 89-90)

The cows in my poems have changed shape. I grew up with Jerseys and Herefords, but now when I think of cows, I see gaur, water buffalo and Brahmans with their delicate neck folds. 
Tropical love has a different quality. No open fires and huddling beneath bed covers. In the tropics everything is more open than that, it's a liquescent feast. Recently, for a short play entitled Sahī, I wrote the following poem:

Anasūyā:

I don't know

you at all

but my heart

has thundered

in my chest

my limbs a

restless monsoon

I am drenched (Hawthorne 2011b)

Cyclones, monsoons, the wild growth of vines, the call of birds, the sea that can be like a mirror or endlessly agitated, these things are now inside me.

\section{From Wind Mind:}

I am in with through the cyclone which is inside with through me the cyclone which is at the heart of things the cyclone which is at the edge of chaos we too are like the swirling objects in a Remedios Varo painting twirling spiralling simultaneously at the edge and at the centre of the universe in a massive creation of life we are the cross-hatched winds of Gungara the spiralling wind from the Kimberleys, we are a poet defiantly writing herself into creation and as I rise from bed to write I see that the dog has a paw across your shoulder and it seems to epitomise what I am struggling to express (Hawthorne 2009: 78)

Living in the torrid zone has brought me to different way of seeing the world. I've had some of my most extreme experiences in the midst of enormous beauty. Twenty-five years ago I wondered at the writings of those whose imaginary worlds are formed by the tropics: the magical realism of Latin American literature is more than a comment on its political history, it is also about the temperature and the humidity. Or take Salman Rushdie's excessive fiction in Midnight's Children. Spend a night in August in India and know that the monsoon affects everything. I am like Kuvalaya who meditates on what it means to travel to unknown places. Kuvalaya is the name for the night lotus. 


\section{what Kuvalaya says}

rain clouds are gathering at the edge of the world when we enter the forest the trees gather their branches over us darken the day shadow hides us from one another

Sarasvati's speech turns our simple words into poetry like the mane of a galloping horse

they call me Kuvalaya the night-opening flower I sing with them carry words to faraway places to a land across the sea where once they say millennia ago some of their ancestors retreated others dispute this and none of the legends is conclusive

I come as a visitor I come with a head full of words full of landscapes and languages whether I find my world in the lyrics of their world is for me to discover here the herd plays I enter this world of shadows of half-told stories where the lotus opens at night (Hawthorne 2011:31)

\section{Works Cited}

Hawthorne, Susan. 2009. Earth's Breath. Melbourne: Spinifex Press.

Hawthorne, Susan. 2011a. Cow. Melbourne: Spinifex Press.

Hawthorne, Susan. 2011b. Sahī: A play. Unpublished.

Hawthorne, Susan. 2012. 'Twenty Stanzas from Meghadūta'. Mascara 11.

Ramanujan, A. K. 2008. Poems of Love and War. New Delhi: Oxford University Press. 